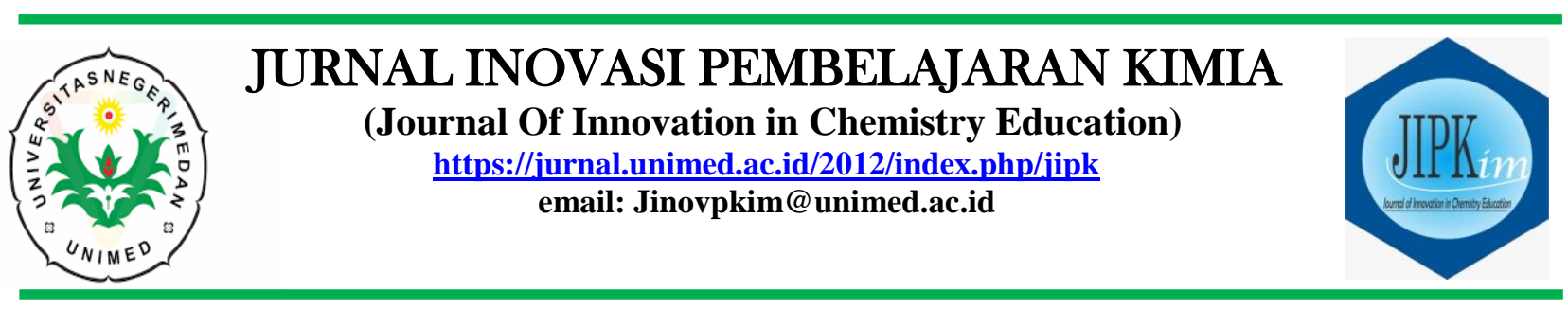

$\begin{array}{ll}\text { Masuk } & : 10 \text { April } 2021 \\ \text { Revisi } & : 13 \text { April } 2021 \\ \text { Diterima } & : 15 \text { April } 2021 \\ \text { Diterbitkan } & : 18 \text { April } 2021 \\ \text { Halaman } & : 11-21\end{array}$

\title{
Pengembangan Pembelajaran Daring Terintegrasi Media Untuk Mengukur HOTS Mahasiswa Pada Mata Kuliah Kimia Organik
}

\author{
Freddy Tua Musa Panggabean ${ }^{1 *}$, Jamalum Purba $^{2}$ dan Marudut Sinaga ${ }^{3}$ \\ ${ }^{1,2,3}$ Program Studi Pendidikan Kimia, Universitas Negeri Medan, Medan \\ *Alamat Korespondensi: freddypanggabean@unimed.ac.id
}

\begin{abstract}
This research includes development research to produce online learning integrates media of Adobe Flash media and the Articulate Story Line and instruments to measure student HOTS in the General Chemistry study. The development model used refers to the ADDIE development model. The result of this research is that the online learning prototype integrated with Adobe Flash and Articulate Story Line and HOTS instruments is valid and effective. Validity is fulfilled qualitatively by the validators. Effectiveness is fulfilled based on the implementation of learning in an integrated media network that students can access online and proven by the increase in students' ability to complete HOTS instruments with the results of $t$-test analysis of 26.607 and $p=0.000$.
\end{abstract}

Keywords: Online Learning, Media of Adobe Flash and Articulate Story Line, HOTS

\section{PENDAHULUAN}

Hasil studi internasional Programme for International Student Assessment (PISA) menunjukkan prestasi literasi membaca (reading literacy), literasi matematika (mathematical literacy), dan literasi sains (scientific literacy) yang dicapai peserta didik Indonesia sangat rendah dan baru bisa menduduki 10 besar terbawah dari 65 negara. Trends in International Mathematics and Science Study (TIMSS) menunjukkan siswa Indonesia berada pada peringkat sangat rendah dalam kemampuan (1) memahami informasi yang kompleks, (2) teori, analisis dan pemecahan masalah, (3) pemakaian alat, prosedur dan pemecahan masalah, serta (4) melakukan investigasi (Nuh, 2014).
Hasil studi PISA yang rendah tersebut tentunya disebabkan oleh banyak faktor dan salah satu faktor penyebabnya adalah karena peserta didik di Indonesia kurang terlatih dalam menyelesaikan soal-soal kontektual, menuntut penalaran, argumentasi dan kreativitas dalam meyelesaikannya, dimana soal-soal tersebut merupakan karakteristik soal-soal TIMS (Fanani, 2018). Berbagai upaya telah dilakukan oleh pemerintah untuk mengatasi permasalahan tersebut termasuk upaya penyempurnaan kurikulum menjadi Kurikulum 2013. Salah satu upaya dalam penyempurnaan Kurikulum 2013 yaitu penyempurnaan pada standar penilaian, dengan mengadaptasi secara bertahap model penilaian standar internasional. 
Penyempurnaan penilaian hasil belajar diharapkan dapat membantu peserta didik untuk meningkatkan kemampuan berpikir tingkat tinggi (Higher Order Thinking Skills/HOTS) serta diharapkan dapat mendorong peserta didik untuk berpikir secara luas dan mendalam tentang materi pembelajaran. HOTS merupakan bagian dari taksonomi Bloom hasil revisi yang berupa kata kerja operasional terdiri dari analisis (C4), evaluasi (C5) dan kreatif (C6) yang dapat digunakan dalam penyusunan soal.

Higher Order Thinking Skill (HOTS) merupakan keterampilan berfikir tingkat tinggi yang menuntut pemikiran secara kritis, kreatif, analitis, terhadap informasi dan data dalam memecahkan permasalahan (Barratt, 2014) dalam (Adri et al., 2020). Berfikir tingkat tinggi merupakan jenis pemikiran yang mencoba mengeksplorasi pertanyaan mengenai pengetahuan yang ada terkait isuisu yang tidak didefinisikan dengan jelas dan tidak memiliki jawaban yang pasti (Haig, 2014) dalam (Nurmala \& Mucti, 2019).

Rendahnya kemampuan berpikir tingkat tinggi bukan hanya dialami oleh siswa di tingkat sekolah, tetapi hal ini juga terjadi pada mahasiswa di perguruan tinggi. Hasil studi awal yang peneliti lakukan, ditemukan masih banyak mahasiswa baru yang kemampuan berpikir tingkat tingginya masih rendah termasuk pada matakuliah Kimia Umum. Hasil analisis peneliti, sebagian besar mahasiswa masih sulit untuk menyelesaikan soal-soal HOTS pada indikator C4-C6.

Pembelajaran merupakan suatu sistem atau proses membelajarkan peserta didik atau mahasiswa yang dirancang, dilaksanakan, dan dievaluasi secara sistematis agar peserta didik dapat mencapai tujuan yang diharapkan. Pembelajaran HOTS adalah pembelajaran yang berorientasi pada keterampilan berpikir tingkat tinggi yang mengajak peserta didik untuk berpikir kritis, kreatif, kolaborasi, dan komunik (Ariyana et al., 2018). Menurut (Hidayati, 2017), menjelaskan bahwa definisi keterampilan berpikir tingkat tinggi dikategorikan ke dalam 3 bagian yaitu sebagai bentuk hasil transfer hasil belajar, sebagai bentuk berpikir kritis, dan sebagai proses pemecahan masalah. Langkah awal pembelajaran HOTS adalah menganalisis kompetensi yang sesuai, karena tidak semua kompetensi dasar yang termuat dalam standar kompetensi lulusan dapat diterapkan pembelajaran HOTS. Untuk itu perlu menganalisis kompetensi dasar yang sesuai.

Seorang pendidik termasuk dosen dituntut untuk dapat merancang strategi/model pembelajaran yang berorientasi pada keterlibatan mahasiswa secara aktif sehingga mahasiswa memiliki kesempatan untuk mengembangkan keteramplan scientifiknya seperti mengamati, menanya, menalar, mencoba, dan mengkomunikasikan serta diharapkan dapat merangsang mahasiswa untuk berpikir tingkat tinggi. Salah satu strategi atau model pembelajaran yang dapat diterapkan dalam mengukur kemampuan berpikir tingkat tinggi (HOTS) mahasiswa adalah dengan menerapkan model pembelajaran berbasis masalah (problem based learning).

Selain penggunaan strategi atau model pembelajaran, faktor lain yang juga perlu dipertimbangkan seorang dosen adalah penggunaan media pembelajaran yang inovatif dan kontruktif dalam merekonstruksi pengetahuan, kemampuan dan kreativitas mahasiswa. Pada era revolusi industri 4.0, berbagai sumber daya manusia dalam semua bidang dituntut memiliki keterampilan digital terlebih dalam bidang pendidikan. Berbagai macam teknologi seharusnya sudah dapat diterapkan dalam kegiatan pembelajaran di kelas. Seorang pendidik baik guru maupun dosen perlu untuk merencanakan strategi maupun media pembelajaran yang inovatif dan kreatif dengan memanfaatkan pembelajaran berbasis teknologi. Salah satu media yang dapat diterapkan dalam proses pembelajaran adalah media Adobe Flash dan Articulate Story Line (berbasis online).

Penggunaan media komputer (multimedia) dapat menjadi alternatif karena dapat mengintegrasikan animasi molekuler 
dan video demonstrasi (Saselah et al., 2017). Perkembangan teknologi memicu berkembangnya e-learning yang pesat, berbagai macam perangkat lunak atau program yang telah disediakan untuk media pembelajaran yang bisa diakses setiap saat dan segala tempat. Perkembangan e-learning memicu terciptanya media pembelajarn interaktif (Busiri \& Suparji, 2015). Penggunaan simulasi komputer dapat membantu dalam meningkatkan pemecahan masalah dan penggunaan aplikasi multimedia meningkatkan proses pembelajaran. Penggunaan multimedia juga memperbaiki miskonsepsi dan misintrepertasi yang terjadi pada pem-belajaran sebelumnya. Penggunaan model media pembelajaran yang memerlukan perangkat keras (hardware) dan perangkat lunak (software) untuk saat ini menjadi sesuatu yang penting untuk diberikan. Salah satu perangkat lunak yang sangat mendukung dalam penerapannya sebagai media pembelajaran interaktif ini adalah Adobe Flash CS6 yang memiliki seluruh elemen multimedia agar nantinya dapat digunakan secara maksimal untuk meningkatkan proses pembelajaran serta prestasi siswa (Romadhon $\&$ Sutopo, 2017).

Salah satu multimedia yang digunakan dalam pengajaran adalah Adobe Flash CS6. Satu aplikasi yang akrab di telinga dan bahan yang sering digunakan untuk mempresentasikan adalah aplikasi Power Point. Tetapi dengan keterbatasan dari PowerPoint aplikasi dalam membuat animasi yang kompleks, lalu peneliti lebih suka aplikasi Adobe Flash CS6 karena aplikasi ini dilengkapi dengan berbagai macam item pendukung dalam membuat animasi (Sukariasih et al., 2019). Aplikasi ini merupakan media yang mengandung unsur gerak, gambar, dan suara. Misalnya dalam bentuk media presentasi, media interaktif (Fauziah et al., 2016). Penggunaan media pembelajaran interaktif dengan Adobe Flash CS6 bisa dijadikan alternatif media pembelajaran, sehingga dengan media pembelajaran interaktif ini mampu menjadikan pembelajaran lebih bervariasi, menarik minat belajar siswa, dan mendapatkan respon positif dari siswa (Busiri \& Suparji, 2015). Dengan media ini diharapkan mahasiswa dapat secara langsung melihat simulasi/gambar yang menyerupai fenomena sebenarnya, sehingga mahasiswa mampu memahami sekaligus. Sesuai dengan penelitian yang dilakukan oleh (Saselah et al., 2017) dengan menggunakan media Adobe Flash CS6 pembelajaran lebih menyenangkan dan berhasil memperoleh respon positif dari para siswa dengan uji coba terbatas sebesar $88,2 \%$ dan setelah mengalami beberapa revisi, pada uji diperluas respon siswa menjadi sebesar 97,8\% yang termasuk pada kategori sangat baik. Begitu juga dengan penelitian Busiri \& Suparji (2015) yang menyatakan bahwa media pembelajaran interaktif menggunakan Adobe Flash CS6 dinyatakan layak untuk dikembangkan dan dapat digunakan sebagai media pembelajaran baik di kelas sebagai pendamping guru maupun dirumah sebagai media belajar siswa dengan perolehan presentase ahli materi $90,66 \%$ dan ahli media $84,11 \%$. Perolehan rata-rata hasil rating pada tiat-tiap resentase adalah $87,38 \%$.

Penggunaan media Articulate Story Line dapat dikembangkan menjadi media pembelajaran untuk mengatasi kesulitan siswa SMP dalam pembelajaran Aljabar dengan menunjukkan nilai rata-rata diatas 75 (Pratama, 2018). Selain itu, Guru juga dapat mengembangkan multimedia pembelajaran interaktif melalui penggunaan aplikasi Articulate Storyline 2 dengan persentase 85\% yang dapat menarik perhatian siswa. Fungsi media pembelajaran diantaranya adalah mengatasi keterbatasan pengalaman yang dimiliki oleh para peserta didik (Darnawati et al., 2019). Media pembelajaran berfungsi menembus batasan ruang kelas, Media pembelajaran berfungsi menjalin interaksi langsung antara peserta didik dan lingkungannya, Media menghasilkan keseragaman pengamatan, Media dapat menanamkan konsep dasar yang benar, konkrit dan realistis, Media membangkitkan keinginan dan minat baru, Media membangkitkan motivasi dan merangsang anak untuk belajar, Media memberikan 
pengalaman yang integral atau menyeluruh dari yang konkrit sampai dengan abstrak (Candra \& Ismayati, 2018).

Perlu adanya media penunjang pembelajaran sehingga siswa mampu memenuhi kebutuhannya masing-masing. Siswa yang masih belum paham dengan materi yang diberikan oleh guru di kelas dapat belajar sendiri dengan media penunjang belajar tersebut di luar kelas. Dengan media penunjang pembelajaran, masing-masing siswa dapat belajar pada kondisi terbaiknya. Yaitu kondisi di saat siswa benar-benar siap untuk menerima materi pembelajaran. Dengan media pembelajaran ber-bentuk video tutorial diharapkan dapat memenuhi kebutuhan dari masing-masing siswa, yaitu siswa dapat belajar dimanapun, kapanpun, dan tentunya dalam keadaan terbaik mereka (Pambudi et al., 2019). Hasil dari project software articulate storyline tidak kalah bagusnya dengan media interaktif lainnya seperti macromedia flash dan adobe flash. Software Articulate Storyline juga dapat diakses secara online atau terkoneksi di internet/web (Purnama \& Asto, 2014). Menurut (Purnama \& Asto, 2014) yang menyatakan bahwa berdasarkan hasil respon siswa, media pembelajaran interaktif menggunakan Software Articulate Storyline mendapatkan hasil rating sebesar $88 \%$. Hasil tersebut terletak pada interpretasi skor $81 \%-100 \%$ sehingga dapat disimpulkan bahwa media pembelajaran interaktif menggunakan Software Articulate Storyline dapat dinyatakan dengan sangat baik. Sama halnya dengan penelitian yang dilakukan oleh (Yumini \& Rakhmawati, 2015) yang memperoleh hasil respon siswa terhadap media pembelajaran interaktif berbasis Articulate Storyline mendapat respon baik. Hal ini diketahui dari hasil penilaian angket respon siswa memeroleh hasil rating sebesar $83,94 \%$ dan dinyatakan sangat baik.

Berdasarkan fenomena dan uraian di atas, maka perlu dikembangkan pembelajaran dalam jaringan terintegrasi media untuk mengukur Higher Order Thinking Skills
(HOTS) mahasiswa pada matakuliah Kimia Umum agar proses pembelajaran dapat terlaksana dengan efektif dan optimal. Pembelajaran yang perlu dikembangkan adalah pembelajaran dalam jaringan berbasis model problem based learning yang terintegrasi media Adobe Flash dan Articulate Story Line (berbasis online) serta instrumen untuk mengukur Higher Order Thinking Skills (HOTS) mahasiswa pada matakuliah Kimia Umum.

\section{KAJIAN LITERATUR}

\section{Pembelajaran Daring (Online)}

Pembelajaran merupakan suatu sistem atau proses membelajarkan peserta didik atau mahasiswa yang dirancang, dilaksanakan, dan dievaluasi secara sistematis agar peserta didik dapat mencapai tujuan yang diharapkan. Seiring perkembangan teknologi dan informasi di era digital saat ini, upaya peningkatan kualitas pembelajaran dapat dilakukan melalui pemanfaatan teknologi dalam suatu sistem yang dikenal dengan pembelajaran dalam jaringan atau online learning.

Pembelajaran dalam jaringan (Online learning) merupakan suatu sistem yang dapat memfasilitasi peserta didik maupun mahasiswa belajar lebih luas, lebih banyak, dan bervariasi. Melalui fasilitas yang disediakan oleh sistem tersebut, mahasiswa dapat belajar kapan dan dimana saja tanpa terbatas oleh jarak, ruang dan waktu. Materi pembelajaran yang dipelajari juga lebih bervariasi, tidak hanya dalam bentuk verbal, melainkan lebih bervariasi seperti visual, audio, dan gerak. Online learning memerlukan peserta didik dan pengajar berkomunikasi secara interaktif dengan memanfaatkan teknologi informasi dan komunikasi, seperti media komputer dengan internet.

Pemanfaatan internet dan komputer sebagai media pembelajaran bergantung pada struktur materi pembelajaran dan bentuk komunikasi yang diperlukan. Beberapa hal penting yang perlu diperhatikan sebagai syarat kegiatan pembelajaran online, antara 
lain: 1) kegiatan pembelajaran dilakukan melalui pemanfaatan jaringan (internet), 2) tersedianya dukungan layanan belajar yang dapat dimanfaatkan oleh siswa atau mahasiswa, 3) tersedianya dukungan layanan tutor (konsultasi) yang dapat membantu peserta belajar jika mengalami kesulitan, 4) tersedianya lembaga yang menyelenggarakan/mengelola kegiatan $e$ learning, 5) sikap positif dari mahasiswa dan dosen terhadap teknologi komputer dan internet, 6) rancangan sistem pembelajaran yang dapat dipelajari/diketahui oleh mahasiswa, 7) sistem evaluasi terhadap kemajuan atau perkembangan belajar mahasiswa, dan 8) mekanisme umpan balik yang dikembangkan oleh lembaga penyelenggaran atau pengelola.

Ciri pembelajaran online antara lain: 1) bertumpu pada kemandirian peserta didik dalam belajar, 2) penggunaan media elektronik berbasis komputer, 3) pemanfaatan berbagai fungsi media elektronik sehingga disebut sebagai Multimedia, dan 4) penggunaan hardware, software, dan jaringan internet (Pannen, 2016) dalam (Irwansyah, 2018), menjelaskan bahwa kunci sukses dalam suatu kelas online bukan pada teknologi apa yang digunakan tetapi bagaimana teknologi tersebut digunakan dan informasi apa yang dikomunikasikan menggunakan teknologi tersebut.

Online learning juga merupakan metode maupun sarana komunikasi yang mampu memberikan manfaat besar bagi kepentingan pengajar (dosen) maupun peserta didik (mahasiswa). Oleh karena itu, para pengajar atau dosen perlu memahami karakteristik atau potensi online learning dengan baik agar dapat dimanfaatkan secara optimal untuk kepentingan pembelajaran para mahasiswanya. Keuntungan online learning adalah media yang menyenangkan, sehingga menimbulkan ketertarikan peserta didik (mahasiswa) pada program-program online. Peserta didik yang belajar dengan baik akan cepat memahami komputer atau dapat mengembangkan dengan cepat keterampilan komputer yang diperlukan, dengan mengakses Web. Oleh karena itu, peserta didik dapat belajar di mana dan kapan saja.

\section{Media Adobe Flash}

Adobe Flash adalah software untuk membuat animasi baik dari gambar, teks, dan suara. Adobe Flash tidak hanya digunakan dalam pembuatan animasi, tetapi pada zaman sekarang ini Adobe Flash juga banyak digunakan untuk keperluan lainnya, seperti dalam pembuatan media pembelajaran interaktif, pembuatan game, membuat web, presentasi dan lain-lain (Busiri \& Suparji, 2015). Adobe Flash CS6 merupakan sebuah program yang mampu mengolah teks serta objek dengan efek tiga dimensi sehingga hasilnya lebih menarik (Romadhon \& Sutopo, 2017). Adobe Flash merupakan program animasi yang mendukung pemrograman dengan Action Script-nya dan program ini tepat digunakan untuk mengembangkan media pembelajaran interaktif (Busiri \& Suparji, 2015).

Adobe flash player CS6 memiliki output format media streaming kecil, yang memiliki keuntungan signifikan selama pengiriman informasi. Adobe flash player CS6 juga sangat interaktif. Itu bisa diintegrasikan dengan banyak perangkat lunak lain dan dikembangkan oleh banyak orang. Selain itu, bahasa dan databasenya lebih kuat daripada versi sebelumnya setelah beberapa pembaruan; semua ini dapat berarti bahwa Adobe flash player CS6 dapat dicapai keunikan dan courseware interaktif (Sukariasih et al., 2019). Selain itu Adobe Flash CS6 juga memiliki fitur yang berektensi tinggi, sehingga media bisa tersimpan dalam handphone agar lebih praktis (Hidayati, 2017).

\section{Media Articulate Story Line}

Articulate Storyline adalah perangkat lunak yang difungsikan sebagai media komunikasi atau presentasi. Media pembelajaran menggunakan software ini tidak kalah menarik dengan media interaktif lainnya (Purnama \& Asto, 2014). Ada 
banyak perangkat lunak authoring yang dapat digunakan untuk membuat multimedia interaktif, salah satunya adalah Articulate Storyline. Articulate Storyline adalah perangkat lunak canggih yang dapat membangun modul e-learning interaktif. Tampilan Articulate Storyline mirip dengan Powerpoint tetapi menawarkan lebih banyak fasilitas (Pambudi et al., 2019). Software Articulate Storyline ini sangat menarik sebagai media pembelajaran interaktif. Program Articulate Storyline mendukung fitur seperti flash dalam pembuatan animasi namun memiliki interface yang simple seperti Power Point. Fitur Articulate Storyline yang lengkap layaknya flash dan interface semudah Power Point menjadikan Articulate Storyline dapat dimanfaatkan sebagai multimedia interaktif. Media ini juga menyediakan berbagai macam template yang bisa digunakan untuk membuat media yang interaktif terutama untuk membuat soal latihan maupun soal tes. Selain itu, program ini memiliki ciri khas yakni terdapat menu seperti tombol zoom untuk memperbesar gambar, tombol tanya untuk melihat penjelasan lebih dalam dari materi, serta tombol navigasi yang berupa next, back dan submit yang selalu berada di bawah layar dan sudah tersedia otomatis di dalam media (Yasin \& Ducha, 2017).

Media pembelajaran berbasis articulate storyline memuat beberapa konten diantaranya teks, audio, gambar, animasi, serta tes evaluasi . Animasi terdapat pada konversi sistem bilangan, hukum aljabar boolean, dan karnaugh map; media pembelajaran berbasis articulate storyline diinstal dan diaplikasikan pada PC (Personal Computer) maupun laptop; media pembelajaran berbasis articulate storyline dijalankan pada windows 7 maupun windows 8; windows harus terpasang flash player 10 atau setelahnya untuk menjalankan media pembelajaran berbasis articulate storyline (Yumini \& Rakhmawati, 2015).

\section{Higher Order Thinking Skills}

Higher Order Thinking Skill (HOTS) atau kemampuan berpikir tingkat tinggi adalah proses berpikir yang mengharuskan siswa untuk memanipulasi informasi yang ada dan ide-ide dengan cara tertentu yang memberikan mereka pengertian dan implikasi baru (Gunawan, 2003) dalam (Fanani, 2018). Menurut (Rosnawati, 2012) seperti dikutip dalam (Fanani, 2018), menjelaskan kemampuan berpikir tingkat tinggi dapat terjadi ketika seseorang mengaitkan informasi yang baru diterima dengan informasi yang sudah tersimpan di dalam ingatannya, kemudian menghubunghubungkannya dan/atau menata ulang serta mengembangkan informasi tersebut sehingga tercapai suatu tujuan ataupun suatu penyelesaian dari suatu keadaan yang sulit dipecahkan. HOTS merupakan bagian dari taksonomi Bloom hasil revisi yang berupa kata kerja operasional terdiri dari analisis (C4), evaluasi (C5) dan kreatif (C6) yang dapat digunakan dalam penyusunan soal (Fanani, 2018). Menurut (Barratt, 2014) dalam (Adri et al., 2020), menjelaskan bahwa Higher Order Thinking Skill (HOTS) merupakan keterampilan berfikir tingkat tinggi yang menuntut pemikiran secara kritis, kreatif, analitis, terhadap informasi dan data dalam memecahkan permasalahan. Menurut (Haig, 2014) dalam (Nurmala \& Mucti, 2019), berfikir tingkat tinggi merupakan jenis pemikiran yang mencoba mengeksplorasi pertanyaan-pertanyaan mengenai pengetahuan yang ada terkait isu-isu yang tidak didefinisikan dengan jelas dan tidak memiliki jawaban yang pasti.

Berdasarkan definisi di atas, kemampuan berpikir tingkat tinggi (Higher Order Thinking Skills/HOTS) merupakan kemampuan atau keahlian berpikir kritis yang termasuk dalam ranah kognitif yaitu kemampuan yang dimiliki peserta didik melakukan proses berpikir kearah analisis, menarik kesimpulan, evaluasi dan kreasi. Kemampuan berpikir ini cenderung untuk mencari kebenaran dari masalah, membuka pemikiran analisis, terurut, sistematik dan ingintahu. HOTS diperoleh dengan latihan memecahkan masalah yang dihadapi oleh peserta didik melalui sejumlah langkahlangkah kegiatan penyelesaian masalah yang 
dilakukan dalam proses pembelajaran, memerlukan ingatan jangka panjang dan sangat berguna bagi peserta didik untuk pembelajaran di masa depannya.

HOTS mengukur kemampuan dalam: 1) transfer konsep, 2) memproses dan menerapkan informasi, 3) mengaitkan berbagai informasi yang berbeda, 4) menyelesaikan masalah dengan menggunakan informasi, dan 5) menelaah ide dan informasi secara kritis. HOTS dimaknai sebagai kemampuan dalam menggunakan pikiran untuk menyelesaikan masalah yang dihadapi. Oleh karena itu, seseorang harus memahami, menafsirkan, menganalisis, serta menginterpretasi informasi. HOTS juga mengajarkan seseorang untuk kritis dalam mengevaluasi informasi, membuat simpulan, serta membuat generalisasi. Dalam Taksonomi Bloom revisi, HOTS merupakan kemampuan kognitif pada tingkat penerapan, analisis, evaluasi, dan inovasi (Mulyaningsih \& Itaristanti, 2018).

Soal-soal HOTS pada konteks asesmen mengukur kemampuan: 1) transfer satu konsep ke konsep lainnya, 2) memproses dan menerapkan informasi, 3) mencari kaitan dari berbagai informasi yang berbeda-beda, 4) menggunakan informasi untuk menyelesaikan masalah, dan 5) menelaah ide dan informasi secara kritis. Meskipun demikian, soal-soal yang berbasis HOTS tidak berarti soal yang lebih sulit daripada soal recall.

\section{METODE}

Penelitian ini termasuk jenis penelitian dan pengembangan. Hasil dari penelitian ini adalah pembelajaran dalam jaringan terintegrasi media Adobe Flash dan Articulate Story Line serta instrumen untuk mengukur Highger Order Thinking Skills mahasiswa pada mata kuliah Kimia Organik.

Penelitian ini dilakukan pada Program Studi Pendidikan Kimia, Jurusan Kimia, Fakultas Matematika dan Ilmu Pengetahuan Alam, Universitas Negeri Medan, Propinsi Sumatera Utara, Indonesia.
Model pengembangan yang digunakan mengacu model pengembangan ADDIE.

Teknik dan instrumen yang digunakan pada penelitian ini antara lain: wawancara, lembar validasi dan tes. Instrumen tes disusun untuk memperoleh data tentang kemampuan berpikir tingkat tinggi mahasiwa. Tes disusun dan dikembangkan sesuai dengan indikator HOTS meliputi C4, C5 dan C6.

Data hasil penelitian dianalisis secara bertahap untuk mengetahui kelayakan (validitas) dan keefektifan pembelajaran yang dikembangkan. Data hasil validasi para ahli dianalisis dengan mempertimbangkan masukan, komentar, dan saran-saran dari validator. Hasil analisis tersebut dijadikan sebagai pedoman untuk merevisi pembelajaran yang dikembangkan. Validitas perangkat pembelajaran yang telah dibuat dapat dilihat dari lembar validasi yang diisi oleh validator ahli dan hasil tanya jawab selama proses validasi. Keefektifan produk pembelajaran yang dikembangkan diperoleh dari hasil tes kemampuan berpikir tingkat tinggi (HOTS) mahasiswa. Uji keefektifan pembelajaran yang dikembangkan dianalisis dari peningkatan HOTS dengan uji-t dengan pendekatan paired sampel t-test dengan bantuan program SPSS.

\section{HASIL DAN PEMBAHASAN}

\section{Hasil Validasi Materi Pembelajaran}

Materi pembelajaran yang divalidasi merupakan materi Kimia Organik. Peneliti menguji kelayakan (validitas) materi pembelajaran yang dikembangkan yang telah divalidasi oleh 3 orang validator ahli yang merupakan Dosen jurusan Kimia program studi pendidikan kimia FMIPA Universitas Negeri Medan. Hasil penilaian validator ahli menunjukkan bahwa dari penilaian (validasi) dari ketiga validator ahli untuk materi Kimia Organik disimpulkan valid (layak) baik pada aspek kelayakan isi, kelayakan bahasa dan aspek kelayakan penyajian. Berdasarkan keterangan aspek penilaian pada tabel 1 di bawah ini dapat dilihat hasil analisis dari ketiga validator. 
Tabel 1. Hasil validasi materi pembelajaran.

\begin{tabular}{|c|c|c|c|c|c|}
\hline \multirow{2}{*}{$\begin{array}{c}\text { Aspek } \\
\text { Penilaian }\end{array}$} & \multicolumn{3}{|c|}{$\begin{array}{c}\text { Validator } \\
\text { (Mean Skor) }\end{array}$} & \multirow{2}{*}{$\begin{array}{l}\text { Total } \\
\text { Mean }\end{array}$} & \multirow[t]{2}{*}{ Kriteria } \\
\hline & I & II & III & & \\
\hline $\begin{array}{l}\text { Kelayakan } \\
\text { Isi }\end{array}$ & 4,25 & 4,13 & 4,00 & 4,13 & Valid \\
\hline $\begin{array}{l}\text { Kelayakan } \\
\text { Bahasa }\end{array}$ & 4,57 & 4,29 & 4,14 & 4,33 & Valid \\
\hline $\begin{array}{l}\text { Kelayakan } \\
\text { Penyajian }\end{array}$ & 4,00 & 4,40 & 4,20 & 4,20 & Valid \\
\hline \multicolumn{4}{|c|}{ Mean Total } & 4,22 & Valid \\
\hline
\end{tabular}

Validator Materi Pembelajaran

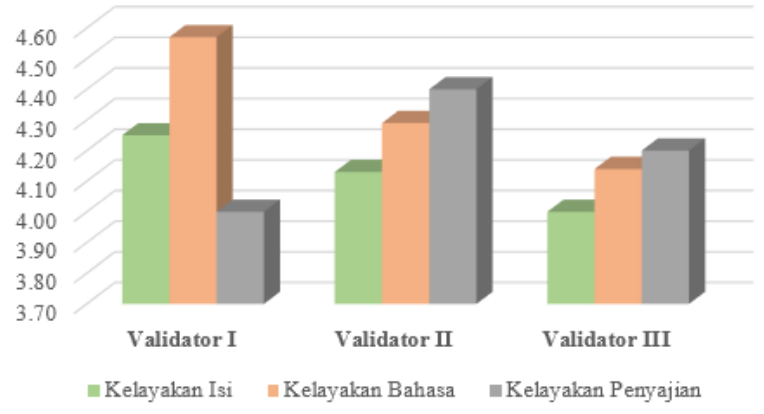

Gambar 1. Validator Materi Pembelajaran

Dengan demikian dari penilaian ketiga validator ahli disimpulkan bahwa materi pembelajaran Kimia Organik yang dikembangkan sudah tergolong valid.

\section{Hasil Validasi Media Pembelajaran}

Kelayakan (validitas) media pembelajaran Adobe Flash dan Articulate Story Line yang dikembangkan divalidasi oleh 3 orang validator ahli. Penilaian (validasi) ketiga validator ahli untuk media pembelajaran Adobe Flash dan Articulate Story Line pada materi Kimia Organik disimpulkan valid baik pada aspek media, tampilan program dan pada aspek kualitas teknis.

Tabel 2. Hasil validasi media pembelajaran.

\begin{tabular}{|c|c|c|c|c|c|}
\hline \multirow{2}{*}{$\begin{array}{c}\text { Aspek } \\
\text { Penilaian }\end{array}$} & \multicolumn{3}{|c|}{$\begin{array}{c}\text { Validator } \\
\text { (Mean Skor) }\end{array}$} & \multirow{2}{*}{$\begin{array}{l}\text { Total } \\
\text { Mean }\end{array}$} & \multirow[t]{2}{*}{ Kriteria } \\
\hline & $\mathrm{I}$ & II & III & & \\
\hline Media & 4,00 & 4,25 & 4,00 & 4,08 & Valid \\
\hline $\begin{array}{l}\text { Tampilan } \\
\text { Program }\end{array}$ & 4,17 & 4,33 & 4,00 & 4,17 & Valid \\
\hline $\begin{array}{l}\text { Kualitas } \\
\text { Teknis }\end{array}$ & 3,88 & 4,38 & 4,25 & 4,17 & Valid \\
\hline \multicolumn{4}{|c|}{ Mean Total } & 4,14 & Valid \\
\hline
\end{tabular}

Validasi Media Pembelajaran

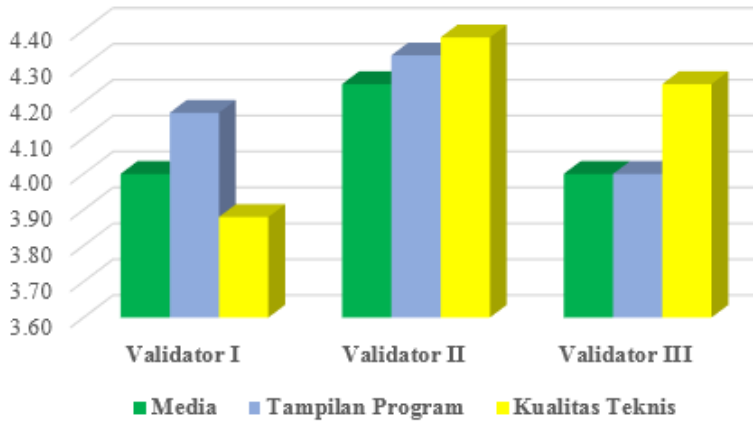

Gambar 2. Validasi Media Pembelajaran

Dengan demikian dari penilaian ketiga validator ahli disimpulkan bahwa media pembelajaran Adobe Flash dan Articulate Story Line (berbasis online) pada materi Kimia Organik yang dikembangkan dinyatakan tergolong valid.

\section{Hasil Validasi Instrumen HOTS}

Kelayakan (validitas) instruments HOTS yang dikembangkan divalidasi oleh 3 orang validator ahli. Penilaian (validasi) ketiga validator ahli untuk instrumen HOTS pada materi Kimia Organik disimpulkan valid baik pada aspek validasi isi, validasi konstruk, bahasa soal dan pada aspek alokasi waktu dan petunjuk.

Tabel 3. Hasil validasi instrumen HOTS.

\begin{tabular}{|c|c|c|c|c|c|}
\hline \multirow{2}{*}{$\begin{array}{c}\text { Aspek } \\
\text { Penilaian }\end{array}$} & \multicolumn{3}{|c|}{$\begin{array}{c}\text { Validator } \\
\text { (Mean Skor) }\end{array}$} & \multirow{2}{*}{$\begin{array}{l}\text { Total } \\
\text { Mean }\end{array}$} & \multirow{2}{*}{ Kriteria } \\
\hline & $\mathrm{I}$ & II & III & & \\
\hline $\begin{array}{l}\text { Validasi } \\
\text { Isi }\end{array}$ & 4,33 & 4,33 & 4,00 & 4,22 & Valid \\
\hline $\begin{array}{l}\text { Validasi } \\
\text { Konstruk }\end{array}$ & 4,50 & 4,50 & 4,50 & 4,50 & Valid \\
\hline $\begin{array}{l}\text { Bahasa } \\
\text { Soal }\end{array}$ & 4,00 & 4,33 & 4,00 & 4,11 & Valid \\
\hline $\begin{array}{l}\text { Alokasi } \\
\text { Waktu dan } \\
\text { Petunjuk }\end{array}$ & 4,00 & 4,00 & 4,00 & 4,00 & Valid \\
\hline \multicolumn{4}{|c|}{ Mean Total } & 4,21 & Valid \\
\hline
\end{tabular}

Validasi Instrumen HOTS

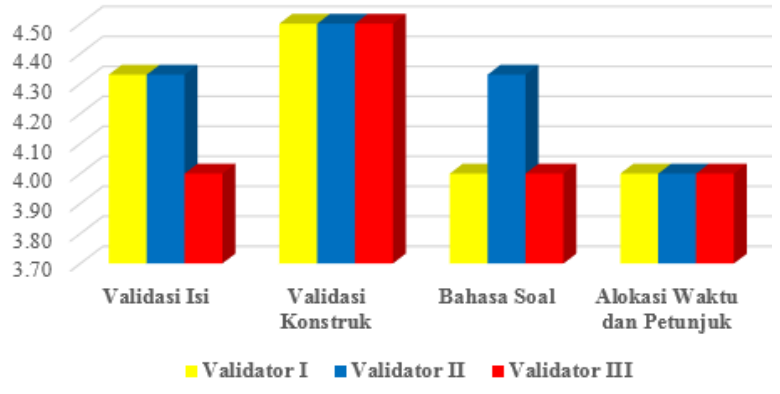

Gambar 3. Validasi Instrumen Hots 
Dengan demikian dari penilaian ketiga validator ahli disimpulkan bahwa secara keseluruhan instrumen HOTS pada materi Kimia Organik yang dikembangkan dinyatakan tergolong valid.

\section{Keefektifan Produk}

Keefektifan produk pembelajaran dalam jaringan terintegrasi media yang dikembangkan dianalisis berdasarkan peningkatan hasil belajar yang diperoleh mahasiswa dalam menyelesaikan tes HOTS pada materi Kimia Organik dengan menggunakan pretest-posttest design. Pengujian dilakukan kepada satu kelompok sampel yaitu sebanyak 30 mahasiswa tanpa ada sampel pembanding (kontrol).

Tabel 4. Deskripsi data HOTS mahasiswa

\begin{tabular}{lrr}
\hline \multicolumn{1}{c}{ Statistik } & Nilai Pretes & Nilai Postes \\
\hline Jumlah Sampel $(\mathrm{N})$ & 30 & 30 \\
Nilai Terendah & 35 & 75 \\
Nilai Tertinggi & 55 & 95 \\
Rata-rata Nilai & 46,67 & 86,17 \\
Standar Deviasi & 5,622 & 5,972 \\
Varians & 31,609 & 35,661 \\
Jumlah Nilai & 1400 & 2585 \\
\hline
\end{tabular}

Lebih lanjut keefektifan pembelajaran dalam jaringan terintegrasi media Adobe Flash dan Articulate Story Line (berbasis online) pada materi Kimia Organik dianalisis dengan pendekatan paired sampel t-test dengan bantuan program SPSS.

Tabel 5. Hasil uji-t

\begin{tabular}{ccccc}
\hline & Mean & T & Df & Sig. \\
\hline Postes - Pretes & 39,500 & 26,607 & 29 & 0,000 \\
\hline
\end{tabular}

Hasil uji-t dengan pendekatan paired sampel t-test diperoleh nilai thitung sebesar 26,607 dengan nilai probabilitas atau Sig sebesar $0,000<0,05$. Dengan demikian, dapat disimpulkan bahwa pembelajaran dalam jaringan terintegrasi media Adobe Flash dan Articulate Story Line (berbasis online) pada materi Kimia Organik efektif dalam mengukur dan meningkatkan HOTS mahasiswa pada materi Kimia Organik.

Besarnya persentase efektifitas pembelajaran dalam jaringan terintegrasi media Adobe Flash dan Articulate Story Line (berbasis online) dalam meningkatkan HOTS mahasiswa pada materi Kimia Organik dapat dihitung dengan nilai gain ternormalisasi, sebagai berikut:

$$
\begin{aligned}
E & =\frac{\text { mean postes }- \text { mean pretes }}{\text { nilai maks ideal }- \text { mean pretes }} \times 100 \% \\
& =\frac{86,17-46,67}{100-46,67} \times 100 \% \\
& =74,07 \%
\end{aligned}
$$

\section{DISKUSI}

Hasil penelitian pengembangan diperoleh produk perangkat pembelajaran dalam jaringan terintegrasi media Adobe Flash dan Articulate Story Line (berbasis online) serta instrumen HOTS yang dinyatakan valid (layak) dan efektif dalam mengukur dan meningkatkan HOTS mahasiswa pada mata kuliah Kimia Organik. Kevalidan (kelayakan) terpenuhi secara kualitatif berdasarkan penilaian (validasi) para validator ahli yang secara keseluruhan dinyatakan dalam kategori valid.

Keefektifan terpenuhi berdasarkan implementasi pembelajaran dalam jaringan terintegrasi media yang dapat diakses mahasiswa secara daring serta dibuktikan dari peningkatan kemampuan mahasiswa menyelesaikan instrumen HOTS pada materi Kimia Organik dengan hasil analisis t-test sebesar 26,607 dan $\mathrm{p}=0,000$ sehingga disimpulkan pembelajaran dalam jaringan yang terintegrasi media Adobe Flash dan Articulate Story Line (berbasis online) serta instrumen HOTS yang valid dan efektif dalam meningkatkan HOTS mahasiswa.

Hasil implementasi terbukti dapat meningkatkan HOTS mahasiswa yaitu sebelum diberikan tindakan dari hasil pretes diperoleh rata-rata nilai HOTS awal mahasiswa sebesar 46,67 dan setelah dilakukan tindakan pembelajaran dalam jaringan yang terintegrasi media Adobe Flash dan Articulate Story Line dari hasil postes diperoleh rata-rata nilai HOTS mahasiswa sebesar 86,17 dengan besarnya persentase keefektifan atau peningkatan HOTS mahasiswa sebesar $74,07 \%$. 


\section{KESIMPULAN}

Hasil temuan penilitan dan analisis data yang dilakukan disimpulkan bahwa produk pembelajaran dalam jaringan terintegrasi media Adobe Flash dan Articulate Story Line (berbasis online) serta instrumen High Order Thingking Skill (HOTS) yang dihasilkan telah memenuhi kriteria valid dan efektif untuk mengukur dan meningkatkan HOTS mahasiswa.

Keefektifan terpenuhi berdasarkan implementasi pembelajaran dalam jaringan terintegrasi media serta dibuktikan dari hasil analisis dengan nilai t-hitung sebesar 26,607 dan $p=0,000$. Hasil tes HOTS mahasiswa dari sebelum (pretes) dan setelah dilakukan tindakan pembelajaran juga terbukti dapat meningkatkan HOTS mahasiswa, dari hasil perhitungan gain ternormalisasi diperoleh persentase peningkatan HOTS mahasiswa sebesar $74,07 \%$.

\section{DAFTAR PUSTAKA}

Adri, H. T., Yudianto, S. A., Mawardini, A., \& Sesrita, A. (2020). Using Animated Video Based on Scientific Approach to Improve Students High Order Thinking Skill. Indonesian Journal of Social Research (IJSR), 2(1), 9-17. https://doi.org/https://doi.org/10.3099 7/ijsr.v2i1.23

Ariyana, Y., Pudjiastuti, A., Bestary, R., \& Zamroni. (2018). Buku Pegangan Pembelajaran Berorientasi pada Keterampilan Berpikir Tingkat Tinggi. In Direktorat Jenderal Guru Dan Tenaga Kependidikan Kementerian Pendidikan Dan Kebudayaan 2018 (pp. 1-95).

Busiri, M., \& Suparji. (2015). Pengembangan Media Pembelajaran Interaktif Dengan Menggunakan Adobe Flash CS6 Pada Mata Diklat Rencana Anggaran Biaya (RAB) Di SMK Negeri 2 Surabaya. Jurnal Kajian Pendidikan Teknik Bangunan, 3(3), 81-91.
Candra, F. A., \& Ismayati, E. (2018). Pengembangan Media Pembelajaran Kemagnetan Listrik Berbasis Computer Based Instruction(CBI) Di SMK NU 1 Sukodadi Lamongan. Jurnal Pendidikan Teknik Elektro, 7(1), 71-77.

Darnawati, Jamiludin, Batia, L., Irawaty, \& Salim. (2019). Pemberdayaan Guru Melalui Pengembangan Multimedia Pembelajaran Interaktif Dengan Aplikasi Articulate Storyline. Amal Ilmiah: Jurnal Pengabdian Kepada Masyarakat, 1(1), 8-16. https://doi.org/Doi:

http://dx.doi.org/10.36709/amalilmiah .v1i1.8780

Fanani, M. Z. (2018). Strategi Pengembangan Soal Higher Order Thinking Skill (HOTS) dalam Kurikulum 2013. Edudeena, 2(1), 5776.

Fauziah, I. Z., Sutrisno, \& Suwarni. (2016). Pengembangan E-Modul Berbasis Adobe Flash CS6 pada Mata Pelajaran Penataan Barang Dagang. Jurnal Pendidikan Bisnis Dan Manajemen, 2(2), 154-159.

Hidayati, A. U. (2017). Melatih Keterampilan Berpikir Tingkat Tinggi Dalam Pembelajaran Matematika Pada Siswa Sekolah Dasar. Jurnal Pendidikan Dan Pembelajaran Dasar, 4(2), 143-156.

Irwansyah. (2018). Penyelenggaraan Sistem Pendidikan Tinggi Jarak Jauh di Perguruan Tinggi Swasta. Jurnal Analisis Sistem Pendidikan Tinggi, 2(1), 39-50.

Mulyaningsih, I., \& Itaristanti. (2018). Pembelajaran Bermuatan HOTS ( Higher Order Thinking Skill ) di Jurusan Tadris Bahasa Indonesia. Jurnal Indonesian Language Education and Literature, 4(1), 114128. https://doi.org/10.24235/ileal.v4i1.29 70 
Nuh, M. (2014). Press Workshop: IMPLEMENTASI KURIKULUM 2013 (pp. 1-115).

Nurmala, R., \& Mucti, A. (2019). Efektivitas Penggunaan LKM Berbasis HOTS (Higher Order Thinking Skills) Terhadap Hasil Belajar Mahasiswa Pendidikan Matematika. Journal of Honai Math, 2(2), 117-128. https://doi.org/http://doi.org/10.30862 /jhm.v2i2.67

Pambudi, P. S., Sujatmiko, P., \& Pambudi, D. (2019). Pengembangan Media Pembelajaran Matematika Berbasis Video Tutorial Dalam Program Komputer Pada Materi Trigonometri Kelas X IPS SMA Negeri 6 Surakarta. Jurnal Pendidikan Matematika Dan Matematika, 3(3), 265-274.

Pratama, R. A. (2018). Media Pembelajaran Berbasis Articulate Storyline 2 Pada Materi Menggambar Grafik Fungsi Di SMP Patra Dharma 2 Balikpapan. Jurnal Dimensi, 7(1), 19-35.

Purnama, S. I., \& Asto, I. G. P. (2014). Pengembangan Media Pembelajaran Interaktif Menggunakan Software Articulate Storyline Pada Mata Pelajaran Teknik Elektronika Dasar Kelas X TEI Di SMK Negeri 2 Probolinggo. Jurnal Pendidikan Teknik Elektro, 3(2), 275-279.

Romadhon, M. M., \& Sutopo. (2017). Pengembangan Media Pembelajaran Teknik Pemesinan Frais Berbasis Adobe Flash CS6. Jurnal Pendidikan Vokasional Teknik Mesin, 5(2), 139144.

Saselah, Y. R., Amir, M., \& Qadar, R. (2017). Pengembangan Multimedia Interaktif Berbasis Adobe Flash CS6 Professional Pada Pembelajaran Kesetimbangan Kimia. Jurnal JKPK (Jurnal Kimia Dan Pendidikan Kimia), 2(2), 80-89. https://doi.org/DOI :

10.20961/jkpk.v2i2.11978
Sukariasih, L., Erniwati, \& Salim, A. (2019). The Development of Interactive Multimedia on Science Learning Based Adobe Flash CS6. International Journal for Educational and Vocational Studies, 1(4), 322$329 . \quad$ https://doi.org/DOI: https://doi.org/10.29103/ijevs.v1i4.14 54

Yasin, A. N., \& Ducha, N. (2017). Kelayakan Teoritis Multimedia Interaktif Berbasis Articulate Storyline Materi Sistem Reproduksi Manusia Kelas XI SMA. Jurnal BioEdu, 6(2), 169-174. http://ejournal.unesa.ac.id/index.php/ bioedu

Yumini, S., \& Rakhmawati, L. (2015). Pengembangan Media Pembelajaran Interaktif Berbasis Articulate Storyline Pada Mata Diklat Teknik Elektronika Dasar Di SMK Negeri 1 Jetis Mojokerto. Jurnal Pendidikan Teknik Elektro, 4(3), 845-849. 